\title{
Communication Pattern and Participation of Custom Village Community in Implementing Tri Hita Karana for Local Custom Conservation at Tourism Destination
}

\section{(Ethnographic Study at Tourism Destination of Peliatan Ubud Custom Village in Gianyar Bali)}

\section{Agus Ardi Sukertha, Rachmat Kriyantono, Sanggar Kanto}

Magister Program of Communication Science, Faculty of Social and Political Sciences, University of Brawijaya, Veteran Road, Malang, 65145

agus.agusardisukertha@gmail.com

Magister Program of Communication Science, Faculty of Social and Political Sciences, University of Brawijaya, Veteran Road, Malang, 65145

$$
\text { rachmat_kr@ub.ac.id }
$$

Magister Program of Communication Science, Faculty of Social and Political Sciences, University of Brawijaya, Veteran Road, Malang, 65145

\section{sanggar.fisip@ub.ac.id}

\begin{abstract}
Research attempts to examine the information about Communication Pattern and Participation of Custom Village Community in Implementing Tri Hita Karana for Local Custom Conservation at Peliatan Ubud Custom Village. Research uses constructivist paradigm with ethnographic method. Main informant is custom leader. Snowball method is used to determine informants until valid information is obtained. Research finds that communication pattern of the community at Peliatan Ubud Custom Village is based on principles of utility, collectiveness and kinship, justice and apportionment, congeniality and harmony. All these principles are reflecting the implementation of Tri Hita Karana. The participation of the community at Peliatan Ubud Custom Village in implementing Tri Hita Karana is shown by conserving their local culture.
\end{abstract}

Keywords: Tri Hita Karana, Communication Pattern and Participation, Conservation of Local Culture

\section{Council for Innovative Research}

Peer Review Research Publishing System

Journal: Journal of Social Sciences Research

Vol .7, No.3

jssreditor.cir@gmail.com

www.jssronline.com 


\section{INTRODUCTION}

Indonesia is a country with enrichment of cultural pluralism. The diversity or pluralism of cultures is a potential that may facilitate the development of welfare and collective understanding of a nation through a program of sustainable community development and empowerment. The optimization of this potential will be a source to foster the well being of the nation. For instance, the potential of communication can be developed through interaction between communities. The form of culture is varying among communities. Immaterial culture may include language, tradition, habit, custom, moral value, ethic, religion, art, kinship system and others, while material culture can involve working tools, farming tools, household appliances, transportation modes, communication devices, and housing or settlement models.

Bali is known as one of tourism destination. It is very popular among Indonesian or even foreigners. The identity of Bali as tourism destination has been described with many words such as beauty, glamour, exotic, conservation, and humbleness and friendliness of the communities. Bali is supported by its custom and culture which emphasize on principles of harmony and balance. These principles are rooted from Hindu Religion and life philosophy of Tri Hita Karana. Both tenets are interrelated. Hindu Religion enlivens Tri Hita Karana and Tri Hita Karana bases its presence upon Hindu Religion.

The proponent of Bali culture is of course the communities of Bali itself. The communities are known as Bali Ethnic or Balinese. As one ethnic, Balinese has ethical identity within themselves or their groups. Gorda (1999; Page 3) defines Bali Ethnic as a group of human tied by one awareness of one culture, either Bali local culture or national culture. Sense of awareness of Bali culture unity is enforced by the unity of language which comprises of Bali language, Hindu language and Bali historical and cultural journeys. The believe onto Hindu Religion has led to the emergence of several traditions, customs, cultures, arts and others which have wide characteristics and which represent the integration of tradition and religion. In daily life, the characteristics are manifested in various conceptions, social activities and physical works of Balinese.

A phenomenon of socio-cultural change due to modernization and globalization which is experienced by Balinese lately has caused a great concern to many elements of Balinese. Some elements assert that Bali is in the middle of challenge or even "threat". The most prominent is a fear that the existence of Tri Hita Karana is threatened to degeneration, along with Hindu Religion and Bali Culture. Globalization and modernization have brought along capitalism and free trade. Foreign capital easily enters the country which may drag Bali into market network ideology and mechanism. The opened fortress cannot escape from the effect of globalization. Market ideology has captured Bali, and thus, the labels such as "MacDonaldization of Bali" or "Coca-Colanization of Bali" are heard very often. These labels refer to the presence of worldclass multinational companies which settle on Bali such as Coca Cola, McDonald, KFC, Pizza Hut, and other products that its headquarter is mostly in America. In other words, Bali can also be illustrated as having symptom "Americanization" or "Westernization" (Pitana, 2002; Page 126).

Such phenomena have indicated that globalization and modernization are big problems which may change something. The potential of socio-cultural change is more evident with the development of tourism because tourism stimulates what so called co-modification. The progress and development of tourism also bring another problem, which is migrant ethnic. Burhanuddin (2009) asserts that the presence of migrant is reflecting the concept of separation and selection between indigenous and migrant through opposite categorization (binary opposition). This condition also shapes the character of Balinese that is fully loaded with suspicion. The character itself is also signified through cultural symbols.

The change due to globalization and modernization, particularly from agriculture to tourism industry, has brought deep impact. Custom Village seems failed to follow the development rate such that the Village is degraded into a status of social organization. The question arises, and it is about how the leadership is communicating this socio-cultural change.

This research explains about socio-cultural aspect in the tourism world. Communication perspective remains in the role of leader which also has engagement into the change of organizational culture at Peliatan Ubud Custom Village, especially in relation with communication pattern and participation of the community at Peliatan Ubud Custom Village in implementing Tri Hita Karana to conserve Bali Culture at Peliatan Ubud Custom Village. Taking account as background the argumentation that one of Indonesian regions which is still conserving its local culture is Bali Island, especially Peliatan Ubud Custom Village. It is important base to this research.

\section{RESEARCH METHOD}

Ethnography research is qualitative research. Ethnography also means an approach to learn socio-cultural aspects of a community, agency and other setting in scientific way. Some research methods and data collection techniques are used to avoid bias and to obtain accurate data.

In general, ethnography has markers distinguishing from other methods of qualitative research. One of markers is data collection technique. Other qualitative research methods are enough with one data collection technique, but ethnography may use four techniques such as field observation, deep interview, FGD and case study.

Ethnography is also called as "describing the community group". Specifically, it also means writing the culture of a community group. Ethnography, therefore, cannot be separated from discussing the definition of culture. The definition of culture itself starts from the sharing process among peoples or organizations about problem of community culture in certain setting. Ethnography becomes an instrument to discuss cultural theories to understand the phenomena observed in the field. Ethnography helps researcher to develop cultural theory or explanation about how peoples think, believe and behave at certain situation in certain space and time (Spreadly, 1997; Page 11). 
Main focus of ethnography is to understand the complex meaning system within the culture. Several meanings are interpreted directly in the language, and most of them are accepted. Other meanings are indirectly expressed through words and deeds (Kriyantono, 2006; Page 67). However, in every community, a meaning is used to regulate the behaviors of community to understand their self and other. In relation to this thesis, the author uses ethnography approach to expose communication pattern and participation of the community in implementing Tri Hita Karana concept for local culture conservation at tourism destination.

\section{DESIGN OF RESEARCH}

Research begins with interviewing main informant. The informant is the leader of Peliatan Ubud Custom Village. It is then followed by interviewing other informants who are selected through Snowball Method which results in 13 persons.

\section{INTERVIEW PROCESS}

Data collection process is direct observation to the questionnaire that is prepared without structure. Questions asked during interview are about communication pattern and participation of the community in implementing Tri Hita Karana for local culture conservation at Peliatan Ubud Custom Village.

The data are narrative texts. However, texts are not well ordered, still overlapped, many repetitions, and excessive. Data are then sorted and arranged into matrix based on problem focus and anything done by custom leader. In such way, communication pattern of the leadership is then understood.

Result of data collection is gross data. To keep in data accuracy, the researcher does double-check few times. Result of interview with one informant is cross-checked with other interview results. Result of interview is also cross-checked with result of observation and FGD. Reconfirmation of result is also important with informants or with other secondary data sources. The important point to consider is the way or the style of interviewing. It is said so because language or questioning pattern, interview setting, and quality of proximity between researcher and informant, can influence the answer or response of informant. Therefore, during data analysis, researcher must not concentrate on answer, but also on the way of asking questions.

\section{RESULT AND DISCUSSION}

\section{Communication Pattern of The Community at Peliatan Ubud Custom Village}

In general, communication pattern of the community at Peliatan Ubud Custom Village is indicated by communication stream of Bottom-Up and Top-Down. Information is generally flown from the leader or elder to the community of Custom Village. It is the yardstick of communication of Custom Village. Each prominent figure in Custom Village always has stronger emotional and spiritual binding with higher level figure, especially the religious figure (Pedanda). The message from Pedanda can be spoken individually or indirectly to the family and community of Custom Village. This communication pattern can be understood by comprehending the values developed at Peliatan Ubud Custom Village. There is a respectable structure which is called as "Pedanda lanang sareng Pedande Istri".

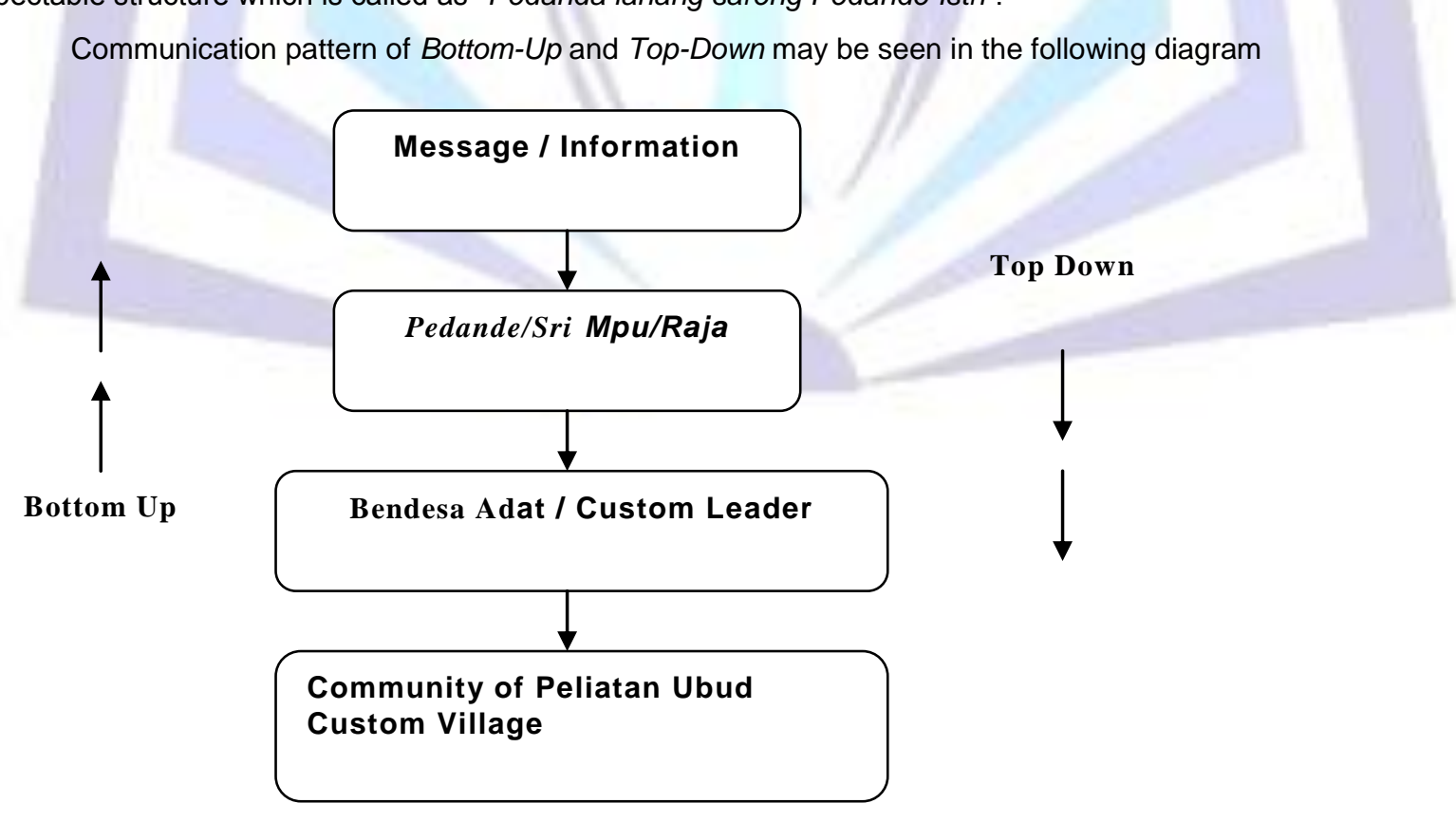

Fig 1: Communication Pattern 


\section{Community Participation in Implementing Tri Hita Karana at Tourism Destination of Peliatan Ubud Custom}

A community participation to implement a policy is by being the member of community group, engaging into the activity, mobilizing the resource of community and participating into decision making. Result of observation indicates that the participation of the community in implementing Tri Hita Karana in tourism destination is active participation in all activities conducted by Peliatan Ubud Custom Village. Several programs are designed to improve the community participation for the interest of tourism progress at Peliatan Ubud Custom Village but local culture and local regulation as stated in awig awig desa cannot be ignored at all. All various activities in Peliatan Ubud Custom Village may not be well implemented if there is no direct participation from the community. It produces a gap and in such, the community does not have knowledge to what is happening. The community is so busy and it leads to less participation in policy making. It will not be surprising if the policy cannot be implemented as expected due to lack of support and participation from the community.

\section{Factors Influencing Participation for Local Culture Conservation at Peliatan Ubud Custom Village}

The task of local culture conservation at Peliatan Ubud Custom Village can only be implemented if several factors are seriously attended. These factors are considered as important for local culture conservation at Peliatan Ubud Custom Village in Bali. These factors are (1) human resource, (2) Peliatan Ubud Custom Village, and (3) the organization of Peliatan Ubud Custom Village. Result of interview has concluded that the participation at Peliatan Ubud Custom Village in implementing Tri Hita Karana is already maximal. Despite the limit, the community itself has an ability to participate into the implementation of Tri Hita Karana. If it is correlated with religiosity and participation rates, community participation is considered as high because the participation is coming from their self voluntarily without being forced.

\section{CONCLUSION AND SUGGESTION}

Communication pattern of the community at Peliatan Ubud Custom Village is based on principles of utility, collectiveness and kinship, justice and apportionment, congeniality and harmony. All these principles are important in the implementation of Tri Hita Karana. The participation of the community at Peliatan Ubud Custom Village in implementing Tri Hita Karana is shown by conserving their local culture. Outside culture may influence the social life of the community, but Tri Hita Karana philosophy remains strong. The culture-related program at Peliatan Ubud Custom Village does not reduce the real significance of Custom Ceremony. Foreigners have acknowledged this ritual as attractive and used it as great motive for their visit.

In general, communication pattern of the community at Peliatan Ubud Custom Village is indicated by communication stream of Bottom-Up and Top-Down. Information is generally flown from the leader or elder to the lay community of Custom Village. It becomes the yardstick of communication at Custom Village. The leadership of Bendesa Adat is significant in creating artifacts from local culture and promoting them as global products by using the power and local wisdom of Custom Village. The community gives their devotion to leadership of Bendesa Adat or Custom Leader, and therefore, the community has awareness that during the communication, Bendesa Adat must have good art of speech within words that can be understood by others, and can also put themselves as good listener or receiver. It means that Bendesa Adat must comprehend and be able to practice Tri Hita Karana. Without such competence, effective communication is hardly produced at Custom Village.

Custom Village embeds philosophy concept of Tri Hita Karana into community leadership, that remains in the hand of Bendesa Adat who always has quite knowledge about the history of Peliatan Ubud Custom Village and its Hindu spiritualism. Besides being the leader, Bendesa Adat is also teacher for Tri Hita Karana philosophy. This philosophy influences the behavior and daily deed of the community. Some factors also influence communication pattern and participation of the community in implementing Tri Hita Karana at tourism destination in Peliatan Ubud Custom Village. These factors also support the local culture conservation at Peliatan Ubud Custom Village in Bali. These factors are: (1) human resource, (2) Peliatan Ubud Custom Village, and (3) organization of Peliatan Ubud Custom Village.

\section{ACKNOWLEDGEMENTS}

It may be suggested that the organization of community needs to develop its own communication pattern which may bring the community into the goal achievement. In recent tendency of community organization, the leader shall influence the community to develop community participation and thus, the implementation of Tri Hita Karana can be realized. Future researcher must use critical ethnography approach to look at communication pattern developed by leadership at Peliatan Ubud Custom Village.

\section{REFERENCES}

[1] Burgoon, J.K, Hoobler. 2002. Nonverbal Signals. In Handbook of Interpersonal Communication. Thousand Oaks,Ca:Sage.

[2] Burhanuddin.Yudhis M. 2008 Bali Yang Hilang: Islam dan Etnissitas Bali, Yogyakarta: Kansius

[3] Creswell,John W. 1998 Qualitative Inuiry and Research Design: Chosing Among Five Traditions,Sage Publications Inc.USA.

[4] Corvarubias,Miguel. 1972. Island of Bali. Oxford University Press Singapore

[5] Geertz Clifford. 1992. The Interpretation of Culture: Selected Essay,London versi Indonesia, Tafsir Kebudayaan Yogyakarta: Kansius. 
[6] Geriya,W. 1976. Sikap Terhadap Pariwisata. Penerbit Kayumas Denpasar

[7] Gorda, I Gusti Ngurah. 1996. Etika Hindu dan Perilaku Organisasi Sekolah Tinggi Ekonomi Satya Dharma.

[8] Gorda,I Gusti Ngurah.1999. Manajemen dan Kepemimpinan Desa Adat di Provinsi Bali dalam Era Globalisasi. Sekolah Tinggi Ekonomi Satya Dharma.

[9] Koentjaraninrat.2009. Pengantar IImu Antripologi Jakarta: PT Rineka Cipta.

[10] Kriyantono,R. 2012a. Etika \& Filsasfat IImu Komunikasi.Malang:UB Press.

[11] Kriyantono,R. 2012b. Public Relations \& Crisis Management. Jakarta: Kencana Prenada Media Group.

[12] Kriyantono,R. 2012c. Public Relations Writing, Teknik Produksi Media Public Relations dan Publisitas Korporat. Jakarta: Kencana Prenada Media Group.

[13] Kriyantono,R. 2012d. Teknis Praktis Riset Komunikasi. Jakarta: Kencana Prenada Media Group.

[14] Pitana, I Gede dan Gayatri Putu G. 2007. Sosiologi Pariwisata, Penerbit: Andi Yogyakarta

[15] Picard,Michael. 2008. Bali Pariwisata Budaya dan Budaya Pariwisata, Penerjemah Jean Counteau dan Warih Wisatsana, Jakarta.

[16] Pitana, I Gede. 1994. Dinamika Masyarakat dan Kebudayaan Bali. Denpasar: PEnerbit Bali Post.

[17] Raka, I Gusti Gede. 1995. Monografi Pulau Bali. Jakarta: Pusat Djawatan Pertanian Rakyat.

[18] Schein, E. H. 1984. Organizational Culture and Leadership. Jossey-Bass Limited. Oxford: Headington Hill Hall.

[19] Spradely, James.P. 1997. Metode Etnografi. Yogyakarta: Tiara wancana.

\section{Author' biography with Photo}

\section{Agus Ardi Sukertha}

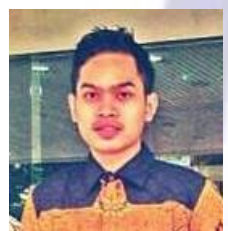

Agus Sukertha has degree from Communication of Undiknas University Denpasar Bali(2012), and he has Master of Communication in FISIP Brawijaya University(2015). His Research interests include Communication Pattern Culture,audiences and interactions.

\section{Rachmat Kriyantono Ph.D}

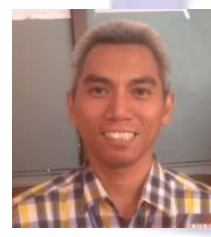

Rachmat Kriyantono is a lecture of Communication and political science department. He has already finish study as master at Airlangga University (2004) and got Ph.D at communication and public relations program at School of Communication, Edith Cowan University, Western Australia (2011).

\section{Prof. Dr. Ir. Sanggar Kanto, MS}

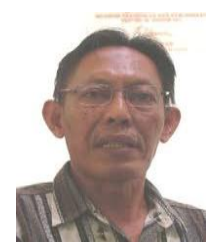

Sanggar Kanto (Surabaya Indonesia 1998) is an Associate Professor of Sociology at University of Erlangga Surabaya Indonesia. His research Labor Mobility of The Village to City Two Rulal Malang East Java. 